\title{
AGENT-CHANGE RELATION: EU MEMBERSHIP AND THE NEW DYNAMICS OF ROMANIAN PUBLIC ADMINISTRATION
}

\author{
Cristina-M aria D ogot \\ University of Oradea \\ Oradea, Romania \\ cdogot@uoradea.ro
}

\begin{abstract}
The first years after 1989, Romanian public administration seemed not to be influenced by the political changes, in the sense of organisational reform. Only in the eve of Romania's accession to European Union, and especially since 2000, when the process of negotiation with the EU officially started, the field of public administration began to be in a higher extent considered for reform. From the end of the nineties to the present time it is possible to reveal two stages of changes related to public administration: those provoked from top down, related to the process of accession to $\mathrm{EU}$, and those from bottom up, related to the process of integration in the EU. The main hypothesis of the article is that EU acted as a direct pressure factor / agent of change in what concerns the organisational reform of Romanian public administration realised during the pre-accession period, while it abandoned this direct role after accession (with some negative consequences). The aim of the present paper is to analyse the dynamic of Europeanisation of Romanian public administration in pre-accession and post-accession periods from the perspective of the organisational reform, realised by adopting the related necessary internal norms according to the Acquis Communautaire.
\end{abstract}




\section{Keywords}

Dynamic of change, Europeanisation, public administration, reform

\section{INTRODUCTORY REMARKS}

The way to (re)organise the public administration of the former communist states, even in different degrees, represented an important challenge both from an internal perspective (how to report to the issue of reform) and from that of accession and integration into a so original and complex supranational organisation as the European Union is. Although not so dramatic in their effects, the first modifications related to the way in which the work of the Romanian administrative system were adopted in 1991, by the new Constitution. Hence, this stipulated "the principle of local autonomy and of decentralisation of public services" (art. 119) and the "autonomous administrative authorities" (art. 120), but for latter it was possible to be established only by organic law (art. 116/3). Although the necessity of reform and modernisation of public administration was experienced from the beginnings ${ }^{1}$, the recently concluded communist period will continue to influence the process of modernisation oriented towards some results as democratisation, transparentisation, debureaucratisation, amongst others. Given the fact that after the end of communism the public administration preserved the majority of its professionals and the same type or hierarchical and functional structures it will be long-time perceived as a very useful instrument that could be legally used by politics (Hințea and Șandor 2000, 30) to impose its decisions, especially that the new political elite was largely represented by a majority of the former communist activists, some of them with a dissident activity overshadowed by some previous political actions related to the

1 "at their beginning after $1989 \ldots$ all the reforms focused mainly on the establishment/re-establishment of basic democratic administrative values and principles." (Bouckaert, Nakrošis, and Nemec 2011, 16) 
communist state ${ }^{1}$ (Pasti 1995, 123; Hințea, Șandor and Junjan 2002, 55-57; Șandor and Hințea 1999; Șuta 1998;). The positive effect of a given efficiency provided by this professional continuity was outclassed by the adverse results: administrative structures maintained the old administration-citizen relations, namely of citizen subordination and domination by administrative structures, and not the opposite, beside the inability or even unwillingness to provide quality services to citizens, according to the specific duties of any administration ${ }^{2}$ (Pasti 1995, 123126, 144-149; Goetz 2001, 1032-1033). As it is possible to see in the following section, only by the late nineties, under the influence of the approaching commencement of the process of the EU accession negotiations ${ }^{3}$, some very important laws related to the interference between public administration and citizens were adopted; nonetheless, in the process of acquiring the membership of the Council of Europe and due to various external financial support, Romania had to adopt some decisions regarding the reform of many fields of public activity, public administration included (Aderarea României; Instrumente juridice; Warner et al.; Hințea, Șandor, and Junjan 2002, 59sqq; Goetz 2001, 1034). At the same time, some elements related to the functional tools and methods to assess the activities of public administration imposed as intrinsic to use in order

${ }^{1}$ For these reasons Goetz (2001, 1038-1043) considered the difficulties in modernising the Eastern European states mainly as a result of their communist legacies, estimated the depoliticisation as "a central plank of administrative reform in the region", and reccomended more conditionalities for the EU accession of the Eastern European states. 2 They are many studies (Popa 2017; Hințea and Neamțu 2014/2015; Săgeată 2012; Berceanu 2012; Hudrea 2014; Moldovan and Macarie 2016) reaching the matter of relations between public administration and citizens as its main beneficiaries or some disfunctionalities and failures of the public administration in its policies concerning regionalisation and/or decentralisation.

${ }^{3}$ This is why some specialists consider that Romania began the reform of its public administration only under the influence of the process of accession to EU and that all the previous adopted norms and changes are insufficient to discuss about reform or modernisation (Tudorel, Profiroiu, and Turturean 2006, 55; Șandor and Tripon 2007, 93$94,100)$. 
to deal with the challenges of Europeanisation process $^{1}$ and its intrinsic conditionalism. Hence, some functional principles as performance, results-based management, leadership skills, the balance between costs and resources, efficiency and effectiveness, transparency, accountability, professionalism (SIGMA-OECD 1998; Nakrošis 2014, 3) were at least formally adopted by the new operational programmes and strategies of reform and modernisation/Europeanisation of the Romanian public administration.

It is well known that the matter of national public administrations does not represent one of the exclusive competencies of the $\mathrm{EU}^{2}$ (but one to support the

${ }^{1}$ Understood in various acceptations, the means that I considered for this paper refer to Europeanisation as process of modification of national laws by adopting the Acquis Communautaire; as a process of modification of the working principles of various public institutions or economic entities according to EU's formal requests; the process of modification of the principles of conduct and action of various institutions and society through voluntary acquisition of European institutional models (Knill 2001; Radaelli $2004)$ or, as Attila Ágh $(2013,741)$ said, of “'domestication' of the European system of democratic institutions", usually with the aim of a future accession to the EU (Goetz 2001, 1037-1038). If usually EU is considered the agent of Europeanisation of different structures and societies, as in a spill-over mechanism, the Romanian public administration in its turn was perceived by EU as an agent of Europeanisation, by the requests of its transformation in a tool "of implementation of European norms" able „to develop the necessary mechanisms to support the participation and to coordinate the activities of Romanian officials in the structures of European Union". This demand will produce some given structural, procedural and content modification of its public policies (Bosovcki 2009), though the process will be a difficult one, with some noticeable failures (Berceanu 2012, 957; Nakrošis 2014, 3-5).

2 The EU was directly interested in reforming this field of activity, given to its major role in applying the acquis communautaire and, not less important, in the general stability and development of economic, social, and cultural environments, the creation of some public values and promotion of democratic principles. (European Commission 2016) On the other side, as for other domains too, the EU was never completely alone in monitoring and supporting the process of reforms in public administration, some other supranational institutions being financially involved in supporting this process: World Bank, International Monetary Fund, OECD (Bouckaert, Nakrošis, and Nemec 2011, 13; Goetz 2001, 1035). 
actions of $\mathrm{MS}^{1}$ ), and because of this fact this field of national activities was not included in a separate chapter of negotiations ${ }^{2}$ and the process of reform was

1 From this perspective it is possible to consider the "structural closure" (Battilana and Casciaro 2012, 383-387) between the EU and its MS as being not so high to provide to the EU a direct causal role of an agent of change (or a „principal-agent," according to Pollack (2005)) in the Romanian administrative field, but one that allotted to Romania, as a candidate State, the possibility to adapt the EU's requests to its particularities. Nonetheless, the analysis of the accession period demonstrate the role and influence of the EU's conditionalism in improving and moving on some processes that, probably, otherwise would have taken much more.

2 However, the consultation of position documents related to all the chapters of negotiations revealed references to the public administration officials, decisions, in the following chapters: 1, Free movement of goods, in relation to the matter of public procurement and the process of monitoring the public free movement of chemical substances and preparations dangerous to humans and the environment; $\mathbf{3}$, Free movement of services, in relation to the necessity of e-government "to ensure the rapid access of citizens and companies to government services"; 5, Companies law, in relation to the training of specialists from public administration in the field; 6, Competition policy, in relation to the role of public administration units in providing the necessary local regulations for the emergence of market competition concerning the local public services; 7, Agriculture, in relation to the establishment of some new public bodies (like the National Cadastre Office), subordinated to the central public administration or of some local responsibilities in the field of animal protection, land fund, etc.; $\mathbf{1 2}$, Statistics, 13, Social policy and employment of labour force, in relation to some specific bodies operating at national level of public administration; 14, Energy, in relation to the role of local public administration in energetic efficiency; 15, Industrial policy, in relation with the administrative barriers and business environment and training for public administration officials; 19, Telecommunications and IT, in relation to the digitalisation of the public administration services and e-government; $\mathbf{2 1}$, Regional policy and coordination of structural instruments, in relation to Nomenclature of Territorial Units for Statistics and public administration units as beneficiaries of the Programme ISPA Environment; 22, Protection of environment, in relation to the role of central and local public administration in protected areas, water and waste management, with the role of public administration in environmental law enforcement and completion of the sewerage and sewage infrastructure; $\mathbf{2 3}$, Health and consumers protection, regarding the collaboration of Consumer Protection Office with central and 
different for each candidate/member state (Bouckaert, Nakrošis, and Nemec $2011,10)$. Despite of this missing capability, "the reform of public administration in the candidate countries has become one of the main EU accession requirements since the EU Summit in Copenhagen in 1993 and Madrid in 1995" (Cardona 2009, 7), and EU refers to the national administrations as constituting the "European Administrative Space", namely one of "a common set of standards for action within public administration, which is defined by national law and enforced through relevant procedures and accountability mechanisms" (Cardona 2009, 7). ${ }^{1}$ Hence, although the candidate states had all the liberty ${ }^{2}$ concerning the means used to reform their public administrations, EU considered the public administrations of the new candidate states from three large perspectives: i./ to be able to accomplish the Criteria of Copenhagen, Madrid and Luxembourg, namely to have the "ability to take on the obligations of membership including adherence to the aims of political, economic and monetary union" in view of implementation of the Acquis Communautaire (European Parliament 1993; Cardona 2009, 3); ii./ structural and investment funds dedicated to economic development of EU's member states could be used as soon as possible by those who need them, and for this purpose, establishing regional structures able to use them was considered necessary; iii./ the role of

local public administration units; $\mathbf{2 4}$, Justice and internal affairs, with regards to fight against organised criminality; 28, Financial control, regarding local taxes, financial activities of public administration units (CLR 2015). The Chapter 30, Institutions, provided the obligation, for Romanian part, to improve the fight against corruption by different means: tests of integrity, public campaigns, direct phone line for complaints of corruption, trainings for public officials, adopting laws of decentralisation, salaries of public officials, establishment of Professionist Body of Prefects (Fuerea et al.).

${ }_{1}$ An indirect presence of EU, especially related to the integration process, could be found in the establishment of some supranational organisations that European Public Administration Network, The Network of Institutes of and Schools of Public Administration in Central and Eastern Europe.

${ }^{2}$ A liberty that was not all the time well managed and which rather disorientated some candidate states and involved, in the end, after accession, a supplementary monitoring period from the part of EU (Societatea Academică din România 2013, 34-37). 
public administration in good governance, namely in its relations with citizens, relations based on citizens' participation in decisional process, the respect of the laws, efficiency, transparency, professionalism and depoliticisation (Comisia Europeană 2015; Asociația Pro Democrația et al. 2007, 6; Șandru and Tripon 2007, 103-104) ${ }^{1}$.

Any of these issues could be analysed from different perspectives, but this is not the objective of this study, that has proposed to focus on regionalisation and decentralisation issues as a result (and condition) of the process of accession and of European integration of Romania (Klárik 2004, 76-77, passim; Balogh 2000, 1213; Bouckaert, Nakrošis, and Nemec 2011, 11) and representing the second dimension of the public administration reform.

Considering all these theoretical perspectives, the hypothesis of the present study is that the EU was the main engine for the post-communist reform of Romanian public administration, according to some areas of the Acquis Communautaire, conditioning these reforms with the objective of Romania's future accession. The study contains both a quantitative and qualitative analysis of the adopted juridical norms that directly supported the second dimension of Europeanisation, that related to the establishment of some new structures, at least theoretically more efficient in the use of the structural funds and, by consequence, very important for the general economic development of the Romanian society. The study is following two directions of research: a horizontal one, referring to the process of Europeanisation in pre-accesion and postaccession period, and a vertical one, referring to the same process from bottomup and from up to down. The conclusions highlight the main results of the study and restate the change-agent role of EU in the case of Romanian public administration. Hence, the aim of the study is to put into evidence in what extent the EU acted as an agent of change in an area for which the acquis is weak represented and its pressures boosted the dynamic of reforms for a given period of time.

${ }^{1}$ An analysis on the official perspective the European Commission has developed on governance and good governance was realised in Ion (2013, 93-98). 


\section{FROM PRE-ACCESSION TO INTEGRATION: LEGISLATIVE AND ORGANISATIONAL APPROACHES}

\subsection{Pre-accession period}

Although it is not really difficult to largely define the pre-accession period, if we consider positions of some researchers (see the note 3) it is possible to split it in almost two chronological stages: one which starts on 22 June 1995, when Romania launched its EU membership application and ends in December 1999, when the European Council from Helsinki decided to accept Romania's demand, and one developed in the framework of negotiations process, started on 15 February 2000 and finished in December 2004, and concluded with the Treaty of accession (25 April 2005) (European Commission 2015; European Council 1999). The 2005-2007 period may be considered as one of completion, related to the preaccession but also with one foot on the boat of integration, and for this reason I considered it somewhat separately.

Therefore, the pre-accession period, with its takeover of Community Acquis, was very important for Romanian public administration reform, for its modernisation, Europeanisation, according to the demands of EU and, in a given extent, to the demands of the economic and social domestic environments. All the above-mentioned directions of interest of EU on the public administration of the candidate states were implicitly included in the chapters of negotiations and materialised, at the end of the negotiation process, in some new judicial norms and some new specialised institutions, subordinated to some of the central bodies of public administration. Taking into account the three dimensions (presented in the introduction) of EU's interest in the public administration of the candidate states, it is possible to reveal three main dimensions of the public administration reform (adopted in the pre-accession period and continued in the period of integration): first is related to its relations with citizens and economic environment; the second concerns the relations between the different levels of the administrative system (local, regional and central), and the last regards the functional capacity of the administrative system (the law of the prefect; the law of public finance and others). It is difficult to establish a hierarchy between the 
three levels of reform, each one being important both by itself and in its interdependences with the other two. These dimensions of reform considered by EU could be retrieved in the directions of public administration reform established by Romanian strategy of reform, and were: strategical (redefining the role of the State in the administrative act), legal (reducing legal confusion by adopting framework laws), organisational (simplification of procedures) and cultural (changing values and mode of action ${ }^{1}$ of elected representatives and local officials ${ }^{2}$.

1 As for example the strategies related to the reform and digitalisation of public administration, adopted in 2001. (Strategia Guvernului 2015, 6-7; Guvernul României. Ministerul Administrației Publice 2015). Hudrea (2014) and Moldovan and Macarie (2016) realised two important approaches of organisational culture and applied their researches on some aspects of organisational culture in Romanian public administration, such as typology of organisational culture, the matter of collectivism, the use of working time, meritocracy, power distance and so one. For this study I considered the organisational processes and the behavioural patterns between the members of the public administration and with its beneficiaries as being very important to be changed in the post-communist period, and I analysed the adopted laws that deserved this approach. Hintea and Mora $(2005,85)$ consider that public organisations "must be able to stimulate the involvement of their members on the basis of understanding values and principles operating in the public domain." Understood from this perspective, the organisational culture of must be "part of the reform", as Șandru and Tripon $(2007,102)$ highlighted too.

2 We could add to the citizens in this approach of culture. For Ágh (2013, 741-742) citizens and their active participation in decisional process are essential in the process of Europeanisation, of reaching the third stage of development of political system, that based on the so "sophisticated" governance, which is, in fact, asked to be reached in the process of European integration in order to recover the "historical delay" between the old and the new members of EU and to provide "the institutional reintegration of the public administration to the public life" (Ágh 2013, 746)). Is also Ágh (2010, 7sqq) who highlighted the increased necessity to reform the EU members' public administrations (especially in terms of performance and effectiveness, the main characteristics of the new public management) in order to better cope with challenges of the international crisis, and pointed out the role allotted to regions by Lisbon Strategy in what concerns both the competitiveness and social cohesion. 
Hundreds of legal norms related to the public administration reform were adopted in the pre-accession period, and a qualitative survey of their content could disclose the main directions they focused (strategical, legal, organisational or cultural). The table below (although not exhaustive) attempts to expose the main legal rules focused on the public administration reform with their focus on the second dimension of reform, that concerning the relations between the different levels of the administrative system.

\begin{tabular}{|c|c|c|}
\hline \multicolumn{3}{|c|}{ Legislation supporting the reform of Romanian public administration } \\
\hline & Legal norm & Direction of reform \\
\hline \multirow{6}{*}{$\begin{array}{l}8 \\
\text { \% } \\
\text { 'े } \\
8\end{array}$} & $\begin{array}{l}\text { Law no. 199/1997 ratifying the European Charter of } \\
\text { Local Self-Government }\end{array}$ & Strategical \\
\hline & $\begin{array}{l}\text { Law no. 151/15 July } 1998 \text { on regional development in } \\
\text { Romania }\end{array}$ & Organisational \\
\hline & $\begin{array}{l}\text { Law } 189 / 1998 \text { on local public finances (amended by } \\
\text { Law } 86 / 1999 \text { ) }\end{array}$ & Organisational \\
\hline & $\begin{array}{l}\text { Law 213/17 N ovember 1998,on public property and } \\
\text { its legal status }\end{array}$ & Organisational \\
\hline & $\begin{array}{llll}\text { Law } 115 / 1999 \text { on ministerial responsibility } \\
\text { (republished in 2007) }\end{array}$ & Organisational \\
\hline & Law 188/1999 on civil service regulations & Organisational \\
\hline & $\begin{array}{l}\text { Law } 5 / 2000 \text { on the approval of the } \mathrm{N} \text { ational } \\
\text { Landscaping Plan - Section III - protected areas }\end{array}$ & Organisational \\
\hline & Law $326 / 2001$, the law of municipal public services & $\begin{array}{l}\text { Organisational, } \\
\text { Cultural }\end{array}$ \\
\hline & $\begin{array}{l}\text { Law } 90 / 2001 \text { on the organisation and functioning of } \\
\text { the Romanian Government and ministries }\end{array}$ & Organisational \\
\hline & $\begin{array}{l}\text { Decision 299/2001 approving the Regulation of } \\
\text { reorganisation and functioning of the } \mathrm{N} \text { ational } \\
\text { A gency of Civil Servants }\end{array}$ & Organisational \\
\hline & $\begin{array}{l}\text { Decision } 336 / 2001 \text {, establishing the } N \text { ational } \\
\text { Committee for Coordination of Rural Development } \\
\text { Project }\end{array}$ & Organisational \\
\hline
\end{tabular}

${ }^{1}$ For an analysis of the problems of reform in this period see Hințea (1999). 


\begin{tabular}{|c|c|}
\hline $\begin{array}{l}\text { Law } 10 / 2001 \text {, on the legal regime of some buildings } \\
\text { taken abusively during } 6 \mathrm{M} \text { arch } 1945 \text { - D ecember } 22 \text {, } \\
1989\end{array}$ & Cultural \\
\hline $\begin{array}{l}\text { Decision no. 951/27 September } 2001 \text { on the } \\
\text { establishment of the Government Council for } \\
\text { monitoring public administration reform }\end{array}$ & Organisational \\
\hline $\begin{array}{l}\text { Decision no. 1006/4 O ctober 2001, approving the } \\
\text { Government Strategy on accelerating public } \\
\text { administration reform }\end{array}$ & Strategical \\
\hline $\begin{array}{l}\text { Decision no. } 1007 / 2001 \text { approving the Government } \\
\text { Strategy regarding the public administration }\end{array}$ & Strategical \\
\hline Law no. $544 / 2001$ on free access to public information & Cultural \\
\hline $\begin{array}{l}\text { Law 215/2001, of public administration (completed by } \\
\text { Emergency Government no.74 / } 2001 \text { and by laws } \\
\text { 216/2002; 141/2004; 286/2006; } 131 / 200835,50,323 \\
\text { and 375/2009,59/2010) }\end{array}$ & Organisational \\
\hline $\begin{array}{l}\text { Ordinance no. } 81 / 2001 \text { on the establishment and } \\
\text { organization of the } \mathrm{N} \text { ational Institute of } \\
\text { Administration by Law } 329 / 2009 \text { repealed and } \\
\text { replaced by GD 1000/2006 }\end{array}$ & Strategical \\
\hline $\begin{array}{l}\text { O rdinance no. 21/2002 on the management of urban } \\
\text { and rural areas - approved by Law no. 515/2002 }\end{array}$ & Strategical \\
\hline $\begin{array}{l}\text { Ordinance no. } 24 / 2002 \text { regarding collection by } \\
\text { electronic means of local taxes - approved by Law no. } \\
522 / 2002\end{array}$ & $\begin{array}{l}\text { Organisational, } \\
\text { Cultural }\end{array}$ \\
\hline $\begin{array}{l}\text { O rdinance no. } 35 / 2002 \text { approving the Regulation for } \\
\text { organizing and functioning of local councils }\end{array}$ & Organisational \\
\hline $\begin{array}{l}\text { Emergency Ordinance no. } 5 / 2002 \text { on imposing } \\
\text { restrictions for local elected officials and civil servants }\end{array}$ & $\begin{array}{c}\text { Organisational, } \\
\text { Cultural }\end{array}$ \\
\hline $\begin{array}{l}\text { Government Decision 209/2002, approving the action } \\
\text { plan for removing administrative barriers in business }\end{array}$ & Cultural \\
\hline $\begin{array}{l}\text { Ordinance no. } 8 / 23 \text { October 2002, to ratify the } \\
\text { Financing M emorandum between the Romanian } \\
\text { Government and the European Commission on } \\
\text { horizontal program to prepare candidate countries for } \\
\text { Extended Decentralisation (EDIS) in the management } \\
\text { of pre-accession funds in Romania }\end{array}$ & Strategical \\
\hline Law $500 / 2002$, on public finances & Organisational \\
\hline
\end{tabular}




\begin{tabular}{|c|c|}
\hline Law $672 / 2002$, on public internal audit & Organisational \\
\hline $\begin{array}{l}\text { Decision no. } 1.555 \text { / } 2002 \text { on the designation of } \\
\text { institutions and bodies responsible for the } \\
\text { coordination, implementation and management of EU } \\
\text { financial assistance through structural instruments }\end{array}$ & \\
\hline $\begin{array}{l}\text { Ordinance no. } 27 / 2003 \text {, amending and supplementing } \\
\text { Law no. 151/1998 on regional development in } \\
\text { Romania }\end{array}$ & Organisational \\
\hline $\begin{array}{l}\text { Law no. 256/10 June } 2003 \text {, approving the } \\
\text { Government O rdinance no. } 27 / 2003 \text { amending and } \\
\text { supplementing the Law no. } 151 / 1998 \text { on regional } \\
\text { development in Romania }\end{array}$ & Organisational \\
\hline $\begin{array}{l}\text { Law } 96 / 2003 \text {, approving Government Ordinance no. } \\
53 / 2002 \text { Framework on the Statute of the } \\
\text { administrativeterritorial unit }\end{array}$ & Legal \\
\hline $\begin{array}{l}\text { Law no. 161/19 A pril 2003, on measures to ensure } \\
\text { transparency in exercising public dignities, public } \\
\text { functions and in the business environment, } \\
\text { preventing and sanctioning corruption }\end{array}$ & Cultural \\
\hline $\begin{array}{l}\text { Law no. } 340 / 12 \text { July } 2004 \text {, on the institution of the } \\
\text { prefect }\end{array}$ & Organisational \\
\hline $\begin{array}{l}\text { Emergency Ordinance no. 56/2004 on the } \\
\text { establishment of the special status of civil servant } \\
\text { called public manager }\end{array}$ & $\begin{array}{l}\text { Organisational, } \\
\text { Cultural }\end{array}$ \\
\hline $\begin{array}{l}\text { Law no. } 7 / 18.02 .2004 \text {, Code of conduct for civil } \\
\text { servants }\end{array}$ & Cultural \\
\hline $\begin{array}{l}\text { Decision no. } 1.083 \text { / } 2004 \text { on the organisation and } \\
\text { functioning of the N ational Institute of } \\
\text { Administration and regional training centres for local } \\
\text { government }\end{array}$ & \\
\hline Law 315/2004, on regional development in Romania & Organisational \\
\hline $\begin{array}{l}\text { Decision no. } 2.001 \text { / } 2004 \text { for the amendment of Art. } \\
18 \text { of Government Decision no. } 497 / 2004 \text { establishing } \\
\text { the institutional framework for coordination, } \\
\text { implementation and management of structural } \\
\text { instruments }\end{array}$ & Organisational \\
\hline $\begin{array}{llllll}\begin{array}{l}\text { Framew ork Law } \\
\text { decentralisation }\end{array} & \text { no. } & 339 / 12 & \text { July } & 2004 & \text { on } \\
\end{array}$ & $\begin{array}{c}\text { Legal, } \\
\text { Organisational }\end{array}$ \\
\hline
\end{tabular}




\begin{tabular}{|c|c|c|}
\hline & $\begin{array}{l}\text { Emergency Ordinance no.111 / } 2004 \text { amending and } \\
\text { supplementing Law no. 315/2004 on regional } \\
\text { development in Romania }\end{array}$ & \\
\hline & $\begin{array}{l}\text { Decision no. } 497 / 2004 \text {, establishing the institutional } \\
\text { framework for coordination, implementation and } \\
\text { management of structural instruments }\end{array}$ & Organisational \\
\hline & $\begin{array}{l}\text { Law 554/2004, the administrative jurisdiction } \\
\text { (amended in } 2007 \text { and 2008) }\end{array}$ & Organisational \\
\hline & $\begin{array}{l}\text { Decision no. 699/2004 approving and updating } \\
\text { government strategy on accelerating public } \\
\text { administration reform for 2004-2006 }\end{array}$ & Strategical \\
\hline & $\begin{array}{l}\text { Decision 1256/2004 approving the Regulation for } \\
\text { organizing and functioning of regional development } \\
\text { councils }\end{array}$ & Organisational \\
\hline & $\begin{array}{l}\text { Decision N o. 772/14 July } 2005 \text { to approve the } \\
\text { organisation and functioning of the } \mathrm{N} \text { ational Council } \\
\text { for Regional Development }\end{array}$ & Organisational \\
\hline & Framew ork Law no. 195/2006 for decentralisation & $\begin{array}{c}\text { Legal, } \\
\text { Organisational }\end{array}$ \\
\hline & Law no. 273/2006 on Local Public Finance & Organisational \\
\hline 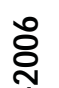 & $\begin{array}{l}\text { Law no. } 286 / 2006 \text { amending and supplementing the } \\
\text { Law no. } 215 / 2001 \text {, on Local Public A dministration }\end{array}$ & Organisational \\
\hline ర్d & $\begin{array}{l}\text { Law no. 181/2006 the approval of O U G no. 179/2005 } \\
\text { amending and supplementing Law no. 340/2004 } \\
\text { regarding the institution of the Prefect }\end{array}$ & Organisational \\
\hline & $\begin{array}{l}\text { Decision no. } 1000 / 2006 \text { on the organization and } \\
\text { functioning of the } \mathrm{N} \text { ational A gency of Civil Servants }\end{array}$ & Organisational \\
\hline & $\begin{array}{l}\text { Emergency O rdinance N } 0.1 \text { / } 2006 \text { on measures to } \\
\text { strengthen administrative capacity for the integration } \\
\text { of R omania into the European U nion }\end{array}$ & Organisational \\
\hline
\end{tabular}

Source: realised by author using information from Indaco LegeStart (2015) and CLR (2015).

The information presented in the table above reveals that the interest of Romanian government for the reorganisation of the public administration was enough important in the period of negotiating the EU's accessing process. As it is possible to observe following this qualitative survey of the main legal norms, the 
perspective of the future integration to EU imposed to Romania some new principles related to the organisation, not only to functionality ${ }^{1}$ of the public administration, as the principle of subsidiarity applied in the process of decentralisation and regionalisation, all with a very well-known double aim: for a closer relation between citizens and decision-makers and to solve the issue of distribution of European structural funds. The organisational approach represented the core of public administration reform in the pre-accession period, and this situation has prompted many complaints from a part of the public opinion, considering the adopted measures as insufficient for a future member state of EU. Assuming and applying the principle of subsidiarity and realising the decentralisation and regionalisation process were some perspectives also approached by some small groups of opinion leaders and some civil organisations ${ }^{2}$ in some key moments and for a short-enough period of time, but without influencing the decision-makers. The visible legislative relaxation ${ }^{3}$ of the

${ }^{1}$ As a result of the new legal rules related to the reform of public administration, some organisations focused on the assessment of the efficiency of this field, were established, although there is not so much data about the results of this assessment process. So, Association of the Economic Directors of County Councils of Romania, by a European funded project, tried "to define, to formulate and to interpret a set of economic and financial indicators for evaluating the effectiveness of local government management, the analysis of performance, and to track how the objectives of the reform are implemented and the decentralisation process is developed." (PNAP 2005a)

2 It is possible to mention especially the following: Proclamation of Timişoara, in 1989; the group "Provincia", 1998-2001 or the members of the group "Liga ProEuropa", 1995-2007; occasional articles in the weekly Revista 22 or in different newspapers. More information about the approaches of the opinion leaders in: Dogot (2006, 103110; Revista 22 2015). The debates organised by opinion leaders were usually related to some events dwell with political discussions or project of law related to the process of regionalisation. Hence, with the exception of some specialists who focus systematically, by their researches, on this process, in the pre-accession period the issue of regionalisation does not really represent a subject matter for public opinion.

${ }^{3}$ Nonetheless, considering the amount of adopted legislative documents, Șandru and Tripon $(2007,103)$ appreciated the public administration as being more dynamic (299 new laws) than health (207) and education system (115 new laws). 
two years before the moment of integration to EU is a proof that Romanian authorities did not assume, in their entirety and with full conviction, those principles and the very concept of public administration reform. It is an incipient phase in this sense ${ }^{1}$, but at the same time it begins the period when Romania will do it not only because of EU pressures, but because of the fact that some rules or principles are implemented with difficulty ${ }^{2}$, the challenges that local public administration are more and more important and various, and so EU will be accompanied in its requirements by some local pressures for reform and modernisation.

As regarding the decentralisation, it represented an objective of all the governments and prime-ministers of the period of pre-accession and integration, and it was intended to be finished until 2008, when the transfer both of attributions and resources had to be realised. With this purpose was adopted the Framework Law 195/2006 on decentralisation (PNAP 2005b), and starting with the same year the government began the restructuration of the central public authorities, under the survey of the Central Unit for Public Administration Reform (established in 2002) (Profiroiu 2002,13-23), but this process has not been without problems. The local authorities had not the experience to manage the public services (schools, hospitals, cultural institutions, sports hall, public safety, social assistance, institutions related to environment and agriculture, asset management), and initially tried to resist accepting new responsibilities, particularly that they were distributed without the necessary funds to achieve them (PNAP 2010b).

From a cu cultural point of view, in 2008, Liviu Radu, the Secretary of the State charged with administration reform in the Ministry of Interior and Administrative Reform, considered that despite of the various training programmes for the public officials, it existed yet, amongst them, "complacency

${ }^{1}$ For example, they were established the principles and the fields of decentralisation and local administrative autonomy but outside of any fiscal decentralisation and autonomy too.

${ }^{2}$ As for example the principle of transparency and predictability of funds allocation, which was not entirely and all the time respected. 
or lack of desire to make reform", lack of planning, lack of a culture of evaluation and of practice of impact analysis (especially at local level). (PNAP 2008) Since 2008 were launched numerous debates related to the financial decentralisation and were adopted new legal norms related to local finances, procurements, deconcentration, healthcare, education, decentralisation of competitions for leading positions. In 2011 the process seems to have become more balanced, though is yet unfinished. The change of government in 2012 and the failure of the process of regionalisation refocused attention of decision-makers on the unachieved objectives of decentralisation and elaborated a new law of decentralisation, but a new failure will be registered when Romanian Constitutional Court considered it as unconstitutional. (Andrei 2013; PNAP 2014a) The presidential elections of the end of 2014 diverted attention of decision-makers from the matter of decentralisation (PNAP 2014d), and so the problem of decentralisation could be found on the agenda of the newly installed government, that of Dacian Cioloș (PNAP 2015a).

\section{THE POST-ACCESSION PERIOD AND THE MATTER OF REFORM : APPROACHES FROM UP TO DOWN}

In order to compare the pre-accession and post-accession periods from the perspective of initiated and realised reforms I used the legislative database Indaco LegeStart and the information retrieved on the national public administration portal, that are the official sources of information for the status of reform of the Romanian public administration. In addition to these sources could be analysed the political positions and programmes related to public administration reform, but I considered the approaches of some other authors (Búkfeyes-Rákossy 2015; Hințea and Neamțu 2014/2015; Nakrošis and Bankauskaitè-Grigaliūnienė 2014; Ágh 2013; Ágh 2010) as being sufficient in arguing the legislative evidences presented bellow.

Although still monitored, in post-accession period Romania seems even more chaotic in terms of the process of reform of public administration. Hence, after its 
accession to EU, the $1^{\text {st }}$ January 2007, Romania stagnated ${ }^{1}$ the process of regionalisation in spite of some less developed and never accomplished political initiatives which rose especially in the period 2011-2013, under the pressure of the new budgetary period of EU, 2014-2020, and of the new rules on financing (PNAP 2013c; 2011a; Hințea and Neamțu 2014/2015, 92, Săgeată 2012). It is possible to assert that, for the post-accession period, the extended role of changeagent from the EU to the Europeanised structures, in our case the public administration, is not (yet) deeply and in a homogenous manner achieved by the administrative units. Different studies show that the level of real compliance with the values and principles of the agent of change modified in the postaccession period for all the states of the Central and Eastern Europe, under the influence of various factors: the objective of accession was reached; before the Lisbon Treaty, the missing capabilities of the EU related to national public administration, and after the failure to apply the new adopted norms and sanctions; political and ideological changes at national level; conservatism and even opposition toward the institutional reform; institutional and cultural differences (Nakrošis and Bankauskaitè-Grigaliūnienè 2014, 6; Bouckaert, Nakrošis, and Nemec 2011; Elbasani 2009, 5). Nonetheless, relevant legal rules related to the cultural aspects were adopted and they started to produces their effects, although the pressure of citizens for this type of changes is not the same for all the units of public administration, and so changes are different for urban and rural areas, as for different regions. As regards the deepening of the organisational reform, this faced both an up to down (rather less) dynamic, and an opposite one, from down to up, but from a different perspective. The first one, from up to down, refers to the essays of the central public administration, by its decision makers, to continue the process of decentralisation and regionalisation, but if decentralisation improved in some aspects, the regionalisation remained unchanged, although in 2014 the Chairman of the Committee for Public

1 Ágh $(2013,743)$ considers this phenomenon of "reform fatigue” as a natural one, in the context of the hard works developed in the candidate states in order to access the EU and the "cumulative" and „stormy transformations" resulted (in a short time) from these efforts. See too Goetz $(2001,1041)$. 
Administration and Spatial Planning of the Chamber of Deputies, Victor Paul Dobre, stated that the "Romanian government has reached its limits and requires a major administrative reform" (PNAP 2015c).

\begin{tabular}{|c|c|c|}
\hline \multicolumn{3}{|c|}{ Legislation supporting the reform of Romanian public administration ${ }^{1}$} \\
\hline \multirow{3}{*}{$\begin{array}{l}\frac{1}{\$} \\
\frac{1}{2} \\
\frac{1}{2} \\
\delta \\
\delta\end{array}$} & Legal norm & $\begin{array}{l}\text { Direction of } \\
\text { reform }\end{array}$ \\
\hline & $\begin{array}{l}\text { Ordinance no. 139/2008 approving the rules for the } \\
\text { application of the Framework Law for } \\
\text { decentralization no. 195/2006 }\end{array}$ & Strategical \\
\hline & $\begin{array}{l}\text { Law no. } 329 / 2009 \text { on the reorganization of public } \\
\text { authorities and institutions, rationalisation of public } \\
\text { expenditure, business support and compliance } \\
\text { framework agreements with the European } \\
\text { Commission and the International M onetary Fund }\end{array}$ & Organisational \\
\hline 2013 & $\begin{array}{l}\text { Decision to amend the Annex of Decision no. } \\
137 / 2013 \text { of Prime minister, on the establishment of } \\
\text { the Inter-ministerial Technical Committee for } \\
\text { regionalization-decentralization }\end{array}$ & Organisational \\
\hline
\end{tabular}

Source: realised by author using information from Indaco LegeStart (2015) and CLR (2015).

A qualitative survey of the references to the regionalisation on the National Portal of Public Administration ${ }^{2}$ could reveal the new dimension of public

${ }^{1}$ To these legal norms is necessary to add the specific organisational rules adopted in the process of decentralisation, but because of their great number we prefer not to enumerate them here.

${ }^{2}$ On the National Portal of Public Administration there are more than 300 articles and links to articles related to the opinions of political leaders and local elected officials on the matter of regionalisation. A qualitative survey on these revealed how much the Romanian officials changed their approach with regards to the necessity of 
administration reform from the perspective of regionalisation. As an example, Vasile Dâncu, one of the leading specialists in the issue of regionalisation and an influential member of one of the political parties who tried constantly, during the pre-accession period, to oppose this process, believes that regionalisation "must be conducted with rationality and targeted primarily on modernising administration", a modernisation consisting in a bigger activism of local administration, possible by another type of education of the public officials, a simplification of bureaucracy ${ }^{1}$, all these being a source, in the end (after one-two decades), of a bigger social cohesion and for fewer gaps between the centre and peripheral regions of Romania. (PNAP 2013j) These ideas were completely impossible for the largest part of politicians of the pre-accession period, and the key characters and the quality of Romanian political class did not change dramatically this time. However, despite the re-launch of debates on regionalisation and of larger public support (PNAP 2013i) than in pre-accession period, some missing elements in achieving this process were, beside some legal aspects (the necessity to modify the Constitution ${ }^{2}$ and some laws), the misunderstandings both with political opposition (in Parliament and at local level, in the public administration units) and the political will. The intended and frequently invoked referendum regarding the modification of Constitution never held, notwithstanding an assessment of the public support for regionalisation, which revealed that Romanians were now largely favourable to this process; the poll opinion revealed that citizens generally supported decentralisation and even

regionalisation and decentralisation, although some conservative voices still persist (PNAP 2015).

1 "Bureaucracy was seen as one of the fundamental explanations for the current crisis of the Romanian administration" (Goudenhooft 2009, 76), and the highly bureaucratised institutions, as the public administration is, are the most resistant to the changes, whatever these changes are asked by citizens (bottom up) of other institutions, even superior institutions (up to down) (Tripon and Ghiolțan 1999; Hințea and Șandor 2000, 29-30 Filip and Onofrei 2000, 115).

${ }^{2}$ Already modified in 2003, so in the period of negotiations, but without considering, at the time, the problem of regionalisation, but, on the contrary, trying to avoid it constantly. 
regionalisation. Endless discussions on regionalisation based on local fears and/or prides ${ }^{1}$, the lack of knowledge and understanding of the advantages of regionalisation in financing the local project, the difficulties in establishing the distribution of financial resources and of attributions, the different plans of politicians and of specialists (PNAP 2006), with the certainty that EU funds will not be lost if the new regionalisation process were not to be achieved, dramatically shortened the time devoted to the regionalization process, leading to its possible delay for 2022 (PNAP 2013d, e). Hence, though not because of it, the EU has not acted as an agent of change in the regionalisation during Romania's integration process. The Euro-parliamentary and presidential elections of 2014 completely removed the attention of decision makers from the matter of regionalisation, and 2015 changed nothing, despite of some expressed intentions in this sense (PNAP 2014b, c). According to the law adopted in 2004, Romanian regions of development "are not administrative units and have no legal personality" (Legea 315/2004). Therefore, they cannot benefit directly from the European funds, and the local autonomy is dramatically limited. After more than ten years of regional experience the specialists considered that a reform of the regional framework would be necessary, especially that in the actual formula authorities failed to obtain the expected effects (SAR 2013, 34-37). However, for the moment, this reform is not on the public agenda.

Nonetheless, despite the failure of renewing the regionalisation process, in February 2013 the Consultative Council for Regionalisation (CONREG), composed of specialists of some universities, local administration officials and NGO's representatives working groups was established and the role of which was "to ensure the necessary expertise in outlining the profile of the future regions" (PNAP 2013a), and the Inter-ministerial Technical Committee for Regionalisation-Decentralisation (CTIRD), whose role has to be "to draw up draft legislation to transfer powers to sectorial categories of administrative units" (CTIRD 2015). In May 2013 the Ministry of Regional Development and Public Administration established its own sub-section dedicated to the matter of

${ }^{1}$ A synthesis of these debates was realised by Zombor Búkfeyes-Rákossy (2015). 
decentralisation-regionalisation (PNAP 2013f), but the page of the Strategy for the Regional Development of Romania, 2014-2020 is yet under construction (the website seems to have not been updated since 2013) (MDRAP 2015a, b). Nevertheless, the government that took office in 19 November 2015 discussed the reform of administration during its first meeting (Ionescu 2015).

\section{THE POST-ACCESSION PERIOD AND THE MATTER OF REFORM : APPROACHES FROM BOTTOM UP}

The economic growth of the period before 2007-2008, the opportunities offered by EU funds and by globalisation, beside certain changes related to the quality of human resource in some important local public administrations (like Cluj, Oradea, Iași) involved a change of the centre of pressure for reform from the central government to local administration units. The modernisation provoked by the local public administration is not so spectacular and so deeply analysed like the changes caused by the EU integration process ${ }^{1}$, and concerns especially the functional dimension of local public administration. Any legal rule adopted following a need of the local units of public administration is directly related (by title of content) to the matter of reform, but most of them were the basis of important changes in terms of some new attributions allotted to the local administration, new resources. So, it is possible to assert that EU was also an indirect agent of change 2 : offering some opportunities to the local levels of public administration it determined new needs and so official requests addressed to the central government. At a formal level, the influence from down to up was

${ }^{1}$ In what concerns the concept of integration, I prefer the approcah of Ágh $(2013,742)$, who consider it as the "further adjustments for the New Member States".

${ }^{2}$ For different kinds of direct and indirect effects EU can induce at national level on polity, politics and policy items, see Ion (2015, 1-17). The study underlines the prominence of indirect EU effects on areas related to polity or politics items, in comparison with the policies subjects where EU has increased capabilities to determine change. 
possible by the different forms of association of the local administrative units, as for example: Association of Towns from Romania; Association of Municipalities from Romania; Federation of Local Authorities from Romania (the latter includes the first two associations and Association of Communes from Romania). Through their representatives, according to their statutes and the legal framework of Romania, the associations, with their proposals, could be part of the central legislative process.

Confronting the bureaucracy of the central government related to the European funds, the local authorities asked for more attributions in direct access of this type of funds, as they asked for more influence of local authorities in establishing the content of the new laws. (Autoritățile locale vor libertate 2009; PNAP 2010a, 2013h, 2013b) Exception of information about the different requests of associations of local authorities to be heard in decisional process and the numerous references of central decision-makers related to the needs of local administrative units, some data or information related to the real influence of the associations of the local administrative units over the legislative decisions were not found. However, despite these difficulties in establishing a direct formal agent-change relation between the local administrative units and the central public authorities, their interaction represent a basis for the next changes in terms of adopted legislation ${ }^{1}$, allotted funds, democratisation of the basis of cooperation, and, in the end, of decentralisation and regionalisation not only by the allocation of competencies from up to down, but by request of major competencies from down to up (as for example the establishment of regions with legal personality and with some limited legislative attributions).

One of the most important directions of reform supported by the local administration concerns the metropolisation (PNAP 2005c) ${ }^{2}$. Although it is also a process started from up to down with the purpose to offer to cities and

${ }^{1}$ During a meeting with the government initiated in December 2015 it was established to develop periodical meetings with the Association of Towns from Romania, in order to discuss the proposal or demands of municipalities with the different responsible ministries. (Portalul Național de Administrație Publică 2015b)

${ }^{2}$ See more about metropolisation in Romania in: Dogot (2013). 
municipalities (and to the communes around them) the possibility to attract and use the Structural Funds for 2007-2013 financial cycle, the legal framework was rather restrictive. The initial legislative framework was not proper in achieving the economic objectives of metropolitan areas (Dogot 2013, 86-87; Hințea and Neamțu 2014/2015, 80-81, 90-91), and in spite of almost immediate pressures from the part of metropolitan areas, the central level delayed in improving it. The most telling example is the project of law of Bucharest Metropolitan Area elaborated in 2003 and which was never adopted. (Garaiman 2013; Legea Zonei Metropolitane București) However, the metropolitan areas act as an agentchange by their important economic role for municipalities and the rural areas around. The expectancies related to the metropolitan areas are very high in Romania, in a great extent because they are yet perceived as producers of local welfare, by opposition to the central - far away and corrupted - government. So, they could be a positive counterexample, the image of a given type of reform under the quiet pressure of which the political (local or central) actors have to reshape their public performance (and so to realise the reform of the public administration too).

\section{CONCLUDING REMARKS}

In the end of the study I may assert that present research confirmed the hypothesis. The quantitative and qualitative data revealed the different dynamic of the Romanian public administration reform for the pre-accession and the postaccession periods. This phenomenon is not a particular one, the studies realised (Hințea and Neamțu 2014/2015; Nakrošis and Bankauskaitè-Grigaliūnienė 2014; Ágh 2013; Bouckaert, Nakrošis, and Nemec 2011, 14-15; Elbasani 2009) for some other post-communist states show that the situation is similar (with some positive and negative differences, it's obvious) for each of these states. For the post-accession period, when Romania has slowed the process of reform in the field of public administration, and so it is possible to consider that the State and its authorities perceived the pre-accession process as a factor of structural closure with the EU, while for the post-accession period, given to the fact that 
administration is "only" a competence of support, cast-off Romania from the 'stress' of reforms in a field that is related to the State, not to the EU competencies. Hence, in this moment it is fair to state that EU represented an agent of change as long as it conditioned the accession of candidate states, though the acquis does not represented an advantageous instrument for the EU in the negotiation process. Once accessed, the new members diminished their interest in organisational reform of the public administration and slowed dramatically the rhythm of changes.

Even if the EU is not directly involved in the continuation of the public administration reforms, it does not completely disappeared from the process of reform. Indirectly, supporting at least partially the financial costs of some supranational organisations and instruments ${ }^{1}$ directly involved in the matter of European public administration (structural and social funds, different programmes related to public administration modernisation, regional policies) to increase the administrative capacity of the new (and old) MS in their efforts to met with the new challenges of integration, on the one side, and of different external factors (as for example the economic globalisation), on the other side.

Albeit they are not directly related to the European system, it is obvious that national public administrations have an important, if not a decisive role, in putting into practice the Community Acquis, in achieving an EU closer to the citizens, in being the 'visible hand' of EU at the lowest possible level. Although from a distance and through the central state bodies, EU was accepted and

${ }^{1}$ As for example the institutions of research in the field of public administration or academic individual research in the field, as the agencies and non-governmental actors that are involved in analysing or supporting the reforms of the public administrations from the MS (two very important examples: European Institute of Public Administration, with its Common Assessment Framework; European Association for Public Administration Accreditation, with a very important role in providing the quality of the training institutes in the field of public administration); European Public Administration Network, an informal network established in the framework of DGs related to public administration, and supporting the cooperation between the public administrations of the MS (EIPA 2017; EAPAA 2017; EUPAN 2017). 
worked as an agent-change for any element of this relation: central public administration, local units of public administration, and, the final beneficiaries, the citizens (for any of these levels, the EU represented an sought catalyst of change, legitimising both the actions and the expectations for action of each of these levels). In their turn, all parts are acting as an external factor for the others, requiring something from each other (becoming an agent-change for the other(s)), and each of them did it on behalf of the EU. This is giving to the principle of subsidiarity ${ }^{1}$, whose application makes either party fail to be selfsufficient $^{2}$. A longitudinal analysis of decentralisation and regionalisation issues revealed this state of affairs, although the effects in Romanian public administration are not yet so significant in depth at any level. Nevertheless, the beginnings of change are already obvious for all the levels (citizens, local and central administration units), despite the low level of decisional maturity of any of these levels.

EU acted as an agent of change up to a certain level, the application of the principles and rules of the reform depending both on the quality of the human resources from the public administration units and on the level of interest of citizens to participate in public decision process. Despite of the great interest of EU in reforming the national administrations, for this case its famous conditionalism could be considered as incomplete as long as EU does not have all the tools of reform in its hands. In the lack of a complete conditionalism the process of Europeanisation is not imposed, but assumed by its various actors who are at the same time the agents and the beneficiaries of changes, and this situation also reduces the role of agent-change of EU. I did not focus on any qualitative variables (social and political backgrounds, political ideologies of domestic actors of regionalisation) in order to demonstrate these conclusions, for this I consider necessary a transversal study, analysing both the programmes

1 "Increasing the role of the regions and of their responsibilities on the basis of the principle of subsidiarity, turns them into carriers of democracy and in major elements of social and political development." (M iclăuș and Horea 2000, 82).

${ }^{2}$ However, it is difficult to say that, after the communist period, we arrived to think and to act according to the principle of subsidiarity. 
dedicated to public administration and to the citizens in their relations with public administration, and the eventual ideological influence on the process of reform (at least for some given periods). It depends by the political and social will of beneficiaries to assume the changes proposed by EU, but first of all by their capacity to understand the long-term consequences of their choices for the society. Another qualitative factor that have to be analysed in order to understand the capacity of Romanian society and political groups to assume the process of reform (and so of Europeanisation) of public administration is that of the common good, a concept that is difficult to say that it is specific for the former communist countries, which communism has learned to detest everything that is common.

The process of Romanian public administration reform is far away to be accomplished, but in the same time the public administration (despite of many internal specificities) is far away from its initial characteristics. Daily realities demonstrate that it is not yet efficient, de-bureaucratised, professionalised and, especially, depoliticised, but for some of its units differences from the beginning of the nineties are really important.

\section{REFERENCES}

- “ “Aderarea României la Consiliul Europei." 2015. [Romania's accession to the Council of Europe]. Accessed October 23. http:/ / coe.mae.ro/node/1252.

- Ágh, Attila. 2013. "Europeanization of Public Administration in Eastern and Central Europe: The Challenge of Democracy and Good Governance." Croatian and Comparative Public A dministration 13: 739-762. Accessed October 10, 2017.

https:/ / pdfs.semanticscholar.org/d324/abc6094ef77aaa866be5ad4b4bb99a9f62a a.pdf.

- Ágh, Attila. 2010. "Europeanization and Democratisation in ECE: Towards Multi-level and Multi-actor Governance." The N ISPA cee Journal of Public Administration and Policy III (1): 7-29. Accessed October 10, 2017. https:/ / www.degruyter.com/downloadpdf/j/nispa.2010.3.issue-1/v10110-0100001-1/v10110-010-0001-1.pdf. 
- $\quad$ Andrei, Cristian. 2013. "Document exclusiv. Guvernul pregătește marea descentralizare" [Exclusive document. The government is preparing the great decentralisation]. $\quad 30 \quad$ September. Accessed November 11. http:/ / www.gandul.info/politica/document-exclusiv-guvernul-pregatestemarea-descentralizare-11418809.

- $\quad$ Andrei, Tudorel, Marius Profiroiu, and Mihai Turturean. 2006. „Reforma administrației publice locale. Cazul României" [Reform of local public administration. The case of Romania]. Economie teoretică şi aplicată [Theoretical and applied economy] 2 (497): 55-64.

- $\quad$ Asociația Pro Democrația, Agenția de Monitorizare a Presei, Centrul de Resurse pentru Participare Publică. 2007. „Buna guvernare la români. Principii, metodologie şi studii de caz" [Good governance in Romania. Principles, methodology and case studies]. Bucureşti. Accessed October 12, 2015. http:/ / www.apd.ro/files/publicatii/Buna_guvernare_la_romani.pdf.

- "Autoritățile locale vor libertate de la Guvern pentru fonduri UE." 2009. [Local authorities want freedom from the Government for EU funds], 08 $\begin{array}{llll}\text { September. } & \text { Accessed November } & \text { 19, }\end{array}$ http:/ / incomemagazine.ro/articles/autoritatile-locale-vor-libertate-de-laguvern-pentru-fonduri-ue.

- Balogh, Marton. 2000. “Apariția politicilor de dezvoltare regională și rolul regiunilor în Europa Centrală și de Est" [The emergence of regional development policies and the role of the regions in Central and Eastern Europe]. Revista Transilvană de Științe A dministrative 1 (4): 7-17. Accessed October 21, 2017. http:/ / rtsa.ro/rtsa/index.php/rtsa/article/view/404/399.

- $\quad$ Battilana, Julie, and Tiziana Casciaro. 2012. "Change Agents, Networks and Institutions: A Contingency Theory of Organizatioal Change." A cademy of M anagement Journal 2 (55): 381-398.

- Berceanu, Bogdan. 2012. "Emerging Administrations under European Union Rules." The 7th Edition of the International Conference European Integration, Realities and Perspectives. Reforming Public Administration. Accessed October 09, 2017. http://www.proceedings.univdanubius.ro/index.php/eirp/article/viewFile/1331/1279.

- Bosovcki, Amanda. 2009. „Administrația publică din România între europenizare şi rezistență la schimbare" [Romanian public administration between Europeanisation and resistance to change]. Sfera Politicii 131-132. Accessed October 08, 2014. http://www.sferapoliticii.ro/sfera/131-132/art12bosovcki.html. 
- Bouckaert, Geert, Vitalis Nakrošis, and Juraj Nemec. 2011. "Public Administration and Management Reforms in CEE: Main Trajectories and Results." The NISPA cee Journal of Public Administration and Policy IV (1): 9-29. Accessed October 10 , 2017. https:/ / www.degruyter.com/downloadpdf/j/nispa.2011.4.issue-1/v10110-0110001-9/v10110-011-0001-9.pdf

- Búkfeyes-Rákossy, Zombor. 2015. Realităţi și perspective ale regionalizării României [Realities and perspectives regarding the regionalisation of Romania]. Revista Transilvană de Științe Administrative 2 (37): 28-37. Accessed October 23, 2017. http:/ / rtsa.ro/rtsa/index.php/rtsa/article/view/509/506.

- Cardona, Francisco. 2009. „Integrating National Administrations into the European Administrative Space." Conference on Public Administration Reform and European Integration Budva, Montenegro 26-27 March 2009. Accessed November 10, 2015. http:/ / www.sigmaweb.org/publications/42747690.pdf.

- Comisia Europeană. 2015. „Extindere. Politica de extindere. Criterii de aderare." [Enlargement. The policy of enlargement. Criteria for accession]. Accessed October 12, 2015. http://ec.europa.eu/enlargement/thepolicy/conditions-for-enlargement/index_ro.htm.

- $\quad$ Comitetul Tehnic Interministerial pentru Regionalizare-Descentralizare (CTIRD). 2015. "Misiune" [Mission]. Accessed November 18. http:/ / regionalizare.mdrap.ro/ctird/misiune/.

- $\quad$ Common Assessment Network (CAF). 2017. Accessed October 31. http:/ / www.eipa.eu/en/topic/show/\&tid=191.

- Consiliul Legislativ Român (CLR). 2015. "Capitolele de negociere ce definesc acquis-ul comunitar" [Chapters of negotiations defining the Community Acquis]. Accessed November 18. http:/ / www.clr.ro/menu1/HtmlPage6.htm.

- Dogot, Cristina-Maria. 2006. "Central and East Europe, the State, and the Challenges of Modernity." In The N ew Central and East European Culture, edited by Steven Tötösy De Zepetnek, Carmen Andras, and Magdalena Markovszky, 100-112. Aachen: Shaker Verlag.

Dogot, Cristina-Maria. 2013. „Economic and Technocratic Leadership at Borderland." In The Frontier W orker - N ew Perspectives on the Labor M arket in the Border Regions, edited by Adrian-Claudiu Popoviciu and Dana Cigan, 81-96. Bucharest: Ed. C.H. Beck.

- $\quad$ Elbasani, Arolda. 2009. "EU Administrative Conditionality and Domestic Downloading. The Limits of Europeanization in Challenging Contexts." KFG 
Working Paper 2 (July): 3-21. Accessed October 28, 2017. http://userpage.fuberlin.de/kfgeu/kfgwp/wpseries/WorkingPaperKFG_2.pdf.

- $\quad$ European Association for Public Administration Accreditation. 2017. Accessed October 31. http://www.eapaa.eu/.

- European Commission. 2015. „EU - Romania Relations.” Accessed October 03, 2015. http://ec.europa.eu/enlargement/archives/romania/eu_romania_relations_en. htm.

- European Commission. 2016. Quality of Public Administration. 14 November. Accessed October 09, 2017. https://ec.europa.eu/info/sites/info/files/european-semester_thematicfactsheet_quality-public-administration_en.pdf.

- $\quad$ European Council. 1999. "Presidency Conclusions. Helsinki European Council 10 and 11 December 1999." Accessed October 03, 2015. http://www.consilium.europa.eu/en/uedocs/cms_data/docs/pressdata/en/ec /acfa4c.htm.

- $\quad$ European Institute of Public Administration. 2017. Accessed November 30. http://www.eipa.eu/.

- $\quad$ European Parliament. 1993. „Copenhagen European Council - 21-22 June 1993. Presidency Conclusions." Accessed October 10, 2015. http://www.europarl.europa.eu/enlargement/ec/cop_en.htm.

- $\quad$ European Public Administration Network. 2017. Accessed October 03, 2017. http://www.eupan.eu/.

- $\quad$ Filip, Gheorghe, and Mihaela Onofrei. 2000. "Fenomenul birocratic în contextul modernizării sistemelor administrative" [Bureaucratic phenomenon in the context of modernising the administrative systems]. Revista Transilvană de Stiințe Administrative 1 (3): 111-118. Accessed October 21, 217. http://rtsa.ro/rtsa/index.php/rtsa/article/view/436/431.

- $\quad$ Fuerea, Augustin, Steliana Sandu, Cezar Scarlat, Gheorghe Hurduzeu, Cristian Păun, and Roxana-Mariana Popescu. 2004. „Evaluarea gradului de concordanță a legislației române cu acquis-ul comunitar, la nivelul anului 2002, pe capitole de negociere" [Assessment of compliance of Romanian legislation with the Community Acquis, in 2002, by negotiating chapters]. Studii de impact (PAIS II). București: Institutul European din România. Accessed November 12. http://beta.ier.ro/documente/studiideimpactPaisII_ro/Pais2_studiu_1_ro.pdf.

- Garaiman, Roxana. 2013. „Zona Metropolitană București scoasă de la nafalină de primarul Oprescu" [Bucharest Metropolitan Area removed from 
naphthalene by Mayor Oprescu]. Business24, 18 October. Accessed November 15, 2015. http://www.business24.ro/administratie/primaria/zona-metropolitanabucuresti-scoasa-de-la-naftalina-de-primarul-oprescu-1536621.

- Goetz, Klaus H. 2001. "Making Sense of Post-communist Central Administration: Modernization, Europeanization or Latinization?" Journal of European Public Policy 8 (6): 1032-1051.

- Goudenhooft, Gabriela. 2009. "A Psychological Interpretation of the Administration Science: The Reform of the Representations." Transylvanian Review of A dministrative Sciences no. 26: 70-81.

- Guvernul României. Ministerul Administrației Publice. 2015. „Strategia Guvernului privind informatizarea administrației publice" [Strategy of government to digitalise the public administration]. Accessed October 10, 2015. http://gov.ro/fisiere/programe_fisiere/e-administration.pdf.

- Hințea, Călin, and Cristina Mora. 2005. "Cultura organizațională în administrația publică" [Organisational culture in public administration]. Revista Transilvană de Științe Administrative 1 (13): 81-86. Accessed October 21, 2017. http://rtsa.ro/rtsa/index.php/rtsa/article/view/216/211.

- Hințea, Călin. 1999. "Probleme strategice ale reformei sistemului administrative românesc" [Strategic issues of the reform of Romanian administrative system]. Revista Transilvană de Științe A dministrative 1 (2): 141-145. Accessed October 21 ,

2017. http://rtsa.ro/rtsa/index.php/rtsa/article/view/458/453.

- Hințea, Călin Emilian, and Sorin Dan Șandor. 2000. "Reformă și administrație publică" [Reform and public administration]. Revista Transilvană de Științe Administrative 1 (3): 29-44. Accessed October 21, 2017. http://rtsa.ro/rtsa/index.php/rtsa/article/view/430/425.

- Hințea, Călin, Sorin Dan Șandor, and Veronica Junjan. 2002. "Administrative reform in Romania and the European Union." Revista Transilvană de Științe Administrative 1 (7): 54-74. Accessed October 21, 2017. http://rtsa.ro/rtsa/index.php/rtsa/article/view/348/343.

- Hințea, Călin E., and Bogdana Neamțu. 2014/2015. “Strategic Planning in the Framework of Metropolitan Areas of Romania: Going beyond the Requirements of the Law and Transforming it into an Effective Planning Tool." The NISPA cee Journal of Public A dministration and Policy VII (2): 71-97. Accessed October 10 , 2017. https://www.degruyter.com/downloadpdf/j/nispa.2014.7.issue-2/nispa-20140004/nispa-2014-0004.pdf. 
- Hudrea, Adrian. 2014. "Studiul și analiza culturii organizaționale" [The study and analysis of organisational culture]. Revista Transilvană de Științe Administrative 2 (35): 29-39. Accessed October 22, 2017. http:/ /rtsa.ro/rtsa/index.php/rtsa/article/view/480/477.

- $\quad$ Indaco LegeStart. 2015. Accessed October 02, 2015.

- "Instrumente juridice semnate şi ratificate de România." 2015. [Legal instruments signed and ratified by Romania]. Accessed October 23, 2015. http:/ / coe.mae.ro/node/1250.

- Ion, Oana-Andreea. 2015. „Europenizarea: un proces, mai multe întrebări” [Europenization: one process, more questions]. In Europenizarea. Studii de guvernare si securitate [Europenization. Governance and Security Studies], edited by Anglițoiu, George, 1-17. Bucharest: CH Beck, Strategic Studies Series.

- Ion, Oana-Andreea. 2013. Abordări actuale ale guvernanți U niunii Europene [Current Approaches to the Governance of the European Union]. Iași, Ed. Polirom.

- Ionescu, Vladimir. 2015. „Prima ședință de guvern: Reforma administrației - Vasile Dîncu, solicitat să gândească principiile, Aura Răducu, să o aplice la administrarea fondurilor europene" [The first meeting of government: Administration Reform - Vasile Dîncu asked to think about the principles, Aura Răducu to apply it to the administration of EU funds], 19 November. Accessed November 19, 2015. http://cursdeguvernare.ro/prima-sedinta-de-guvernreforma-administratiei-vasile-dincu-solicitat-sa-gandeasca-principiile-auraraducu-sa-o-aplice-la-administrarea-fondurilor-europene.html.

- Knill, Christoph. 2001. The Europeanisation of $\mathrm{N}$ ational Administrations. Patterns of Institutional Change and Persistance. New York: Cambridge University Press.

- Legea 315/2004, privind dezvoltarea regională în România [Law 315/2004 on regional development in Romania]. Accessed November 18, 2015. http:/ /lege5.ro/Gratuit/gu3domrv/legea-nr-315-2004-privind-dezvoltarearegionala-in-romania.

- Legea Zonei Metropolitane București. 2015. [Law of Bucharest Metropolitan Area] in: http://zmb.ro/main.php?display=proiect_final. Downloaded: 15/11/3015.

- Miclăuș, Gheorghe, and Nicolae Horea. 2000. „Instrumente de cooperare ale colectivităţilor locale şi regionale în cadrul național şi internațional” [Tools of cooperation for local and regional units within the national and international 
framework]. Revista transilvană de ştiințe administrative 2 (4): 81-91. http://rtsa.ro/rtsa/index.php/rtsa/article/view/411.

- Ministerul Dezvoltării Regionale și Administrației Publice (MDRAP). 2015a. Accessed November 18, 2015. http:/ / www.mdrap.gov.ro/.

- _ - _ 2015b. "Când se vor constitui regiunile?.” [When will regions be established?]. Accessed November 2015. http:/ / regionalizare.mdrap.ro/despre-regionalizare/cand-se-vor-constituiregiunile/.

- Moldovan, Octavian, and Felicia Cornelia Macarie. 2016. "Cultura organizațională în administrația publică: o analiză comparativă" [Organisational culture in public administration: a comparative analysis]. Revista transilvană de ştiințe administrative 2 (39): 123-139. Accessed October 23, 2017. http:/ /rtsa.ro/rtsa/index.php/rtsa/article/view/536/533.

- Nakrošis, Vitalis, and Sabina Bankauskaitè-Grigaliūnienè. 2014. "Public Administrations Changes and the Impact of the EU: Agencification and Depoliticisation in Central and Eastern Europe." Paper for the ECPR joint sessions (Salamanca, 2014), Vilnius. Accessed October 08, 2015. https:/ / ecpr.eu/Filestore/PaperProposal/5a110089-7378-41af-ba367e39f13612a5.pdf.

- The Network of Institutes of and Schools of Public Administration in Central and Eastern Europe. 2017. Accessed October 03, 2017. http://www.nispa.org/.

- $\quad$ Pasti, Vladimir. 1995. România în tranziție. Căderea în viitor [Romania in transition. The fail in the future], Bucureşti, Ed. Nemira.

- $\quad$ Pollack, Mark A. 2005. "Theorizing EU Policy-Making." In Policy M aking in the European U nion, edited by Helen Wallace, William Wallace, and Mark A. Pollack, 13-48. Oxford: Oxford University Press.

- Popa, Florin Marius. 2017. "Assessment of Public Administration Integrity Level: Between Morality and the Law." Romanian Journal of Public A ffairs no. 1: 28-36.

- $\quad$ Portalul Național de Administrație Publică [National Portal of Public Administration]. 2015. Accessed

October

31. http:/ / www.administratie.ro/cautare.php.

- $\quad$ Portalul Național de Administrație Publică (PNAP). 2005a. “ADECJR a editat o broșură privind analiza managerială a administrației publice locale" [ADECJR edited a brochure on local government management analysis], 31 
March. Accessed November 15, 2015. http:/ / www.administratie.ro/articol.php?id=277\&indentifica=descentralizare. - - - 2013a. „A fost înființat CONREG, organism strategic prevăzut în Memorandumul privind procesul de regionalizare" [CONREG was established, a strategic body provided in the Memorandum on the process of regionalisation]. Accessed November

04, 2015. http:/ / www.administratie.ro/articol.php?id=42628\&indentifica=regionalizare. - - - - 2013b. „Asociația Oraşelor din România se declară împotriva adoptării actualului proiect de lege privind descentralizarea" [Association of Towns from Romania are against the adoption of the current draft law on decentralisation]. 04 November. Accessed November 19, 2015. http:/ / www.administratie.ro/articol.php?id=45158\&indentifica=descentralizare

- - - 2014a. “CCR a decis că legea descentralizării încalcă principiul autonomiei locale, al legalității şi regimul proprietății" [CCR decided that the law of decentralisation violates the principle of local autonomy, of legality and property]. 12 January. Accessed November 19, 2015. http:/ / www.administratie.ro/articol.php?id=45771\&indentifica=descentralizare

- - C-. 2013c. „Cristian Pârvulescu: 'Până acum, împărțirea României s-a făcut în mod arbitrar'" [Until now, the division of Romanian territory was arbitrary]. 04 March. Accessed November 12, 2015. http:/ / www.administratie.ro/articol.php?id=42775\&indentifica=regionalizare.

- - - 2006. „Deputați PNL lucrează la un proiect de lege pentru regionalizarea țării" [Liberal MPs working on a bill to regionalize the country]. $05 \quad$ June. Accessed November 01, 2015. http:/ / www.administratie.ro/articol.php?id=8761\&indentifica=regionalizare. - $\quad$ - —. 2010a. "Descentralizarea a fost principala temă abordată la reuniunea Asociației Orașelor din România" [Decentralization was the main topic discussed at the meeting of the Association of Towns from Romania]. 25 January. Accessed November 19, 2015. http:/ / www.administratie.ro/articol.php?id=29356\&indentifica=descentralizare

- - - 2005b. "Descentralizarea va fi finalizată până în 2008, potrivit unui proiect de lege" [According to a bill, decentralisation will be completed by 2008], 03 November. Accessed Noember 19, 2015. http:/ / www.administratie.ro/articol.php?id=4574\&indentifica=descentralizare. 
- - - - 2005c. "Dezvoltare metropolitană în Romania" [Metropolitan development in Romania], 31 October. Accessed November 15, 2015. http:/ / www.administratie.ro/articol.php?id=4519\&indentifica=descentralizare.

- - —. 2011a. "Emil Boc: 'Dacă nu facem reorganizarea administrativteritorială, România îşi diminuează şansele de a mai accesa fonduri europene'" [Emil Boc: 'If we fail to do the administrative-territorial reorganisation, Romania diminishes its chances to access European funds'], 07 June. Accessed November 19 ,

2015.

http:/ / www.administratie.ro/articol.php?id=36520\&indentifica=descentralizare

- $\quad$ - - 2011b. „Fostul director al INA: 'Regionalizarea este necesară numai pentru a duce la dezvoltarea socio-economică'" [Former director of INA: 'Regionalisation is necessary only to lead to socio-economic development']. 09 June. Accessed November 03, 2015. http:/ / www.administratie.ro/articol.php?id=36544\&indentifica=regionalizare.

- - - . 2011c. "Gheorghe Nichita: 'Regionalizarea este aruncată în derizoriu de către guvernanți'" [Regionalisation is a mockery of the governors]. 16 June. Accessed November 03, 2015. http:/ / www.administratie.ro/articol.php?id=36625\&indentifica=regionalizare. - $\quad$ - - . 2013d. „Klaus Iohannis despre regionalizare: 'Aproape sigur că nu o facem anul acesta, dar nu există un risc de a pierde banii UE'" [Klaus Johannis about regionalization: 'Almost certainly we will not do it this year, but there is no risk of losing EU money']. 02 August. Accessed November 14, 2015. http:/ / www.administratie.ro/articol.php?id=44250\&indentifica=regionalizare.

- $\quad$ - - - 2014b. "Klaus Iohannis crede că regionalizarea nu se va face anul acesta, 'din cauza alegerilor'" [Klaus Johannis believes that regionalisation will done not be this year, 'because of the election']. 23 January. Accessed November 14 , 2015. http://www.administratie.ro/articol.php?id=45909\&indentifica=regionalizare. - - —. 2013e. „Liviu Dragnea: 'România este dezvoltată dezechilibrat, abordarea față de regionalizare e diferită față de începutul anului'" [Liviu Dragnea: 'Romania is unequally developed, the approach towards regionalisation is different from the beginning of this year']. 24 October. Accessed November 14, 2015. http:/ / www.administratie.ro/articol.php?id=45052\&indentifica=regionalizare.

- - - . 2013f. „MDRAP a lansat pe site-ul propriu secțiunea regionalizare-descentralizare" [MDRAP released on its website a section on 
regionalisation-decentralisation]. 16 May. Accessed October 11, 2015. http:/ / www.administratie.ro/articol.php?id=43546\&indentifica=regionalizare.

- - —. 2013g. „Ministrul Liviu Dragnea explică de ce regiunile din România trebuie să fie funcționale până în decembrie 2013" [Minister Liviu Dragnea explains why Romanian regions have to work until December 2013]. Accessed November 03, 2015. http:/ / www.administratie.ro/articol.php?id=42352\&indentifica=regionalizare.

- - - — 2008. "Nu a existat dorința de a reforma administrația" [There was no will to reform administration]. 10 November. Accessed November 19, 2015.

http:// www.administratie.ro/articol.php?id=22598\&indentifica=descentralizare

- - - 2015a. "Obiectivele și principiile Programului de guvernare propus de Cabinetul Cioloș" [The objectives and principles of governing program proposed by the Cioloş Cabinet]. 16 November. Accessed November 19, 2015.

http:/ / www.administratie.ro/articol.php?id=50772\&indentifica=descentralizare

- - - - 2015b. "O delegație a Asociației Municipiilor din România a avut o întâlnire cu vicepremierul Vasile Dîncu" [A delegation of the Association of Towns from Romania had a meeting with the vice-prime-minister Vasile Dîncu]. 13 December. Accessed December 13, 2015. http:/ / www.administratie.ro/articol.php?id=50953.

- - _ - 2010b. "Primarii oraşelor mici sunt nemulțumiți că nu au fonduri şi că nu există descentralizare locală" [Mayors of small towns are unhappy that they have no funds and there is no local decentralisation]. 12 March. Accessed November 19 , 2015. http:/ / www.administratie.ro/articol.php?id=30263\&indentifica=descentralizare

- - - - 2013h. „Procesul de descentralizare a fost discutat de conducerea MDRAP cu asociațiile administrat,iei publice locale" [The decentralization process has been discussed by the management of local government associations MDRAP]. $23 \quad$ April. Accessed November 19, 2015. http:/ / www.administratie.ro/articol.php?id=43371\&indentifica=descentralizare

- - - 2 2013i. "Românii au mari aşteptări de la regionalizare” [Romanians have high expectations from regionalization]. 12 April Accessed 
October

12 ,

2015

http:/ / www.administratie.ro/ articol.php?id=43245\&indentifica=regionalizare.

- ———. 2013j. „Vasile Dâncu: "Regionalizarea trebuie să vizeze în primul rând modernizarea administrației'" [Regionalization should primarily focus on the modernization of administration]. 29 March. Accessed November 14 ,

2015

http:/ / www.administratie.ro/articol.php?id=43079\&indentifica=regionalizare.

- - - . 2014c. "Vicepremierul Liviu Dragnea speră că 2015 va fi anul în care se vor finaliza descentralizarea şi regionalizarea" [Vice-prime-minister Liviu Dragnea hopes that 2015 will be the year that will complete decentralisation and regionalisation]. 14 September. Accessed November 14, 2015. http:/ / www.administratie.ro/articol.php?id=47731\&indentifica=regionalizare.

- - - 2015c. "Victor Paul Dobre: 'Administrația publică, atât centrală cât şi locală, şi-a atins limitele'" [Victor Paul Dobre: 'Public administration, both central and local government, has reached its limits']. 15 October. Accessed November 14 , 2015 http:/ / www.administratie.ro/articol.php?id=50486\&indentifica=regionalizare. - - - . 2014d. "Victor Ponta: 'În 2015 chiar trebuie să facem descentralizarea'" [Victor Ponta: 'In 2015 we really need to realise decentralisation']. 29 June. Accessed November 19, 2015. http:/ / www.administratie.ro/articol.php?id=47419\&indentifica=descentralizare

- Profiroiu, Marius. 2002. „Accelerarea reformei administrației publice” [Acceleration of reforms of public administration]. Revista Transilvană de Științe Administrative 2 (8): 13-23. Accessed November 23, 2015. http://rtsa.ro/rtsa/index.php/rtsa/article/view/318/313.

- Radaelli, Claudio M. 2004. „Europeanisation: Solution or Problem?” European Integration online Papers (EIoP), 16 (8). Accessed October 12, 2015. http://eiop.or.at/eiop/texte/2004-016a.htm.

- Săgeată, Radu. 2012. "Reformele administrative din România - între rațiunile politice și realitățile geografice" [Administrative reforms in Romania between political motivation and geographical realities]. Geograful III (1-2): 3-26. Accessed October 28, 2017. http://apgr.eu/downloads/Geograful\%20_1_2_2011.pdf.

- $\quad$ SIGMA-OECD. 1998. „Principiile europene în administrația publică” [European principles in public administration]. Paris. 
- Societatea Academică din România (SAR). 2013. "Raport anual 2013" [Annual report 2013]. Accessed November 18, 2015. http://sar.org.ro/wpcontent/uploads/2013/03/RAPORT-SAR_FINAL.pdf.

- "Strategia Guvernului privind accelerarea reformei în administrația publică" [Strategy of government to accelerate the reform in public $\begin{array}{llll}\text { administration]. } & \text { Accessed } & \text { October } & 1015 .\end{array}$ http:/ / gov.ro/fisiere/programe_fisiere/reforma-admin-public.pdf.

- S S Sandor, Dan, and Călin Hințea. 1999. "Profesionalizarea funcționarilor publici" [Professionalization of public officials]. Revista Transilvană de Științe Administrative 1 (2): 83-93. Accessed October 21, 2017. http:/ /rtsa.ro/rtsa/index.php/rtsa/article/view/453/448.

- S Sandor, Sorin Dan, and Ciprian Tripon. 2007. "Pași spre construirea unui model operațional al reformei administrației publice" [Steps to build an operational model of public administration reform]. Revista Transilvană de Știinte Administrative 1 (19): 92-106. Accessed October 21, 2017. http:/ /rtsa.ro/rtsa/index.php/rtsa/article/view/165/161.

- Șuta, Ștefan. 1998. "Necesitatea profesionalizării și reformei administrației publice" [Need for professionalization and public administration reform]. Revista Transilvană de Științe Administrative 1 (1): 11-19. Accessed October 21, 2017. http:/ / rtsa.ro/rtsa/index.php/rtsa/article/view/371/366.

- Tripon, Ciprian, and Călin Ghiolțan. 1999. "Rezistența la schimbare" [Resistance to change]. Revista Transilvană de Științe A dministrative 1 (2): 94-115. Accessed October 21, 2017. http://rtsa.ro/rtsa/index.php/rtsa/article/view/454/449.

- Warner, Martin, Cezar Scarlat, and Daniel Popescu. 2015. "Implicații ale aderării României la UE asupra instituțiilor din administrația publică" [Implications of Romania's EU accession on public administration institutions]. Accessed October 21, 2015. http:/ / beta.ier.ro/documente/studiideimpactPaisI_ro/Pais1_studiu_B-5_ro.pdf. 